\title{
Optimized Design of a Hybrid Biological Sewage Treatment System for Domestic Wastewater Supply
}

\author{
Benjamin K. Kogo1, Elijah K. Biamah², Philip K. Langat ${ }^{3}$ \\ ${ }^{1}$ Environment Department, Norken International Limited, Nairobi, Kenya \\ ${ }^{2}$ Department of Environmental and Bio-Systems Engineering, University of Nairobi, Nairobi, Kenya \\ ${ }^{3}$ School of Environmental and Rural Science, University of New England, Armidale, Australia \\ Email: benkogo@gmail.com
}

How to cite this paper: Kogo, B.K., Biamah, E.K. and Langat, P.K. (2017) Optimized Design of a Hybrid Biological Sewage Treatment System for Domestic Wastewater Supply. Journal of Geoscience and Environment Protection, 5, 14-29.

https://doi.org/10.4236/gep.2017.55002

Received: March 28, 2017

Accepted: May 8, 2017

Published: May 11, 2017

Copyright $\odot 2017$ by authors and Scientific Research Publishing Inc. This work is licensed under the Creative Commons Attribution International License (CC BY 4.0).

http://creativecommons.org/licenses/by/4.0/

\begin{abstract}
This study is aimed at evaluating alternative designs of waste stabilization ponds (WSPs) and constructed wetlands (CWs) for Kaputiei Housing Estate consisting of 2000 low cost housing units in Kenya. The entire analysis was carried out by simulating the effectiveness and purification efficiencies of WSPs and CWs in terms of Biological Oxygen Demand (BOD) reduction and faecal coliform (FC) removal under different scenarios of water treatment systems that included Re-sizing of the initial sewage treatment system, optimizing the design of the initial system and design of hybrid system for the estate. The graphic comparison of the simulated parameters under different scenarios showed that a hybrid design that combines both the WSPs and CWS provides an effluent BOD of 20 $\mathrm{mg} / \mathrm{l}$ and $195 \mathrm{FC}$ per $100 \mathrm{ml}$ that meets the standard effluent discharge that is acceptable for unrestricted crop irrigation and thus will be reused in the housing estate for kitchen gardening and agroforestry.
\end{abstract}

\section{Keywords}

Wastewater, Waste Stabilization Ponds, Constructed Wetlands, BOD, Faecal Coliforms, Purification

\section{Introduction}

Pollution of the environment and in particular of water resources as a result of poor waste management including sanitation constitutes one of the most immediate and serious environmental problems facing governments around the world, particularly in developing countries. Urbanization and economic development are now changing the face of the earth dramatically and remain power- 
ful drivers of pollution. Between 1970 and 2000, the global population doubled 6 billion while the degree of urbanization in developing countries rose by half to reach $50 \%$ and these countries' economies grew tenfold from US $\$ 0.4$ to 4 trillion [1]. Industrial cities with factories are the engine for economic development, but also consume more resources and use up more space forcing all waste to be discharged into the "nature" beyond these cities' borders [2]. The pollution load into the environment has increased concomitantly, thus is exerting pressure on nature and threatening economic activities [3] [4]. The Commission on Sustainable Development has raised concern over current patterns of development, utilization and management of water resources [5]. Current patterns of water use globally are not sustainable [6] and the world is facing a worsening series of local and regional water quality problems, partly as a result of unregulated effluent disposal especially in poor developing countries [3] [7] despite requirements of modern and sustainable Development Goals.

More than 1.7 billion people in urban and rural areas do not have appropriate sanitary facilities and approximately $80 \%$ of all diseases and a third of all deaths are caused by inadequate water and lack of hygiene in developing countries [1]. This is a tragedy that has been called "the 'silent emergency'-a global crime against humanity" [8].

In Kenya, the demand for urban settlements especially for the poor urban dwellers has remarkably increased over the years necessitating sprang up of slum dwellings. These urban and peri-urban dwellings are often constraint by land space and lack proper planning of sewage disposal systems. Even where there are well designed sewer lines, the people living in the slums have ended up perforating and conveying the tapped raw sewage to their vegetable gardens. Because of the risks associated with the abstraction of raw sewage that is polluted by heavy metals such as arsenic and lead, and other toxic pollutants that are translocated by plants, it is imperative that means of safe disposal of raw sewage in unplanned urban and peri-urban settlement areas be sought. A well planned and efficient liquid waste treatment system allows for the recycling of quality waste water in households and thus significantly reducing the per capita water demand for fresh water. This study is aimed at evaluating alternative designs of waste stabilization ponds and constructed wetlands in space constraint urban and peri-urban settlement areas.

\section{Description of Study Area}

The study area was Kaputiei Housing Estate located in Kisaju in, Kajiado County where 2,000 low cost housing units were being developed. It is situated at an altitude range of $1650 \mathrm{~m}$ and $1680 \mathrm{~m}$ above sea level $50 \mathrm{~km}$ South East of Nairobi City. Kaputiei is an undulating ridge area lying between two seasonal rivers (Kisaju to the south and Engejolorowak to the north) and is in a semi-arid environment. This semi-arid area falls within agro-climatic zone $4 / 5$ which is a typical semi-arid environment with medium potential for agriculture. Kaputiei soils are predominantly deep (one meter) black cotton soils (vertisols) with a sandy 
clay loam texture. The Kaputiei (new) Town area has black cotton soil within the top 0 to $1.0 \mathrm{~m}$ depth and weathered limestone within a depth of 1.0 to $2.0 \mathrm{~m}$ and is underlain by weathered Upper Athi Tuffs (volcanic tuffs or building stones) at depths greater than $2.0 \mathrm{~m}$ [9]. In some areas, the black cotton soil is to a depth of $65 \mathrm{~cm}$ and is above a limestone layer of 1 to $1.4 \mathrm{~m}$ depth. The parent material comprises of deep phonolitic basement system rock.

\section{Methodology}

\subsection{Determination of Design Input Parameters}

The standard design models that are applicable to sewage treatment systems (STSs) in Kenya were used in determining the input design parameters that included:

i) Design population $(\mathrm{Pd})$

The population projection for the STS is adopted from the Practice Manual for Water Supply Services in Kenya (2005) that recommends that water supply systems be designed for a 20 year period.

The design population for the waste treatment system for the estate was based on an initial population of 10,000 people and a design period of 20 years. Equation (1) was used in estimating the initial, future and ultimate population.

$$
p_{d}=P_{i}(1+r)^{n}
$$

where, $P_{d}=$ design population, $P_{i}=$ initial population, $n=$ design period, $r=$ annual population growth rate expressed as a fraction.

Based on the above, the design population was as follows: Initial population10,000; Future Population-14,802; and Ultimate Population-21,911.

ii) Design BOD concentrations

The design BOD concentration was estimated on the basis of wastewater contribution of 100 liters/capita/day and per capita BOD contribution of $40 \mathrm{mg} / \mathrm{day}$ [10] that is recommended for medium-sized towns that Kaputiei Housing Estate falls. The wastewater BOD from the estate was estimated using Equation (2) applicable to Tropical climates [11]:

$$
L_{i}=1000 \frac{B}{q}
$$

where: $L_{i}$ is wastewater BOD $(\mathrm{mg} / \mathrm{l}) ; B$ is BOD contribution (g/capita/day); and $q$ is wastewater flow (L/capita/day).

iii) Design flows

The amount of wastewater generation was estimated as a factor of water consumption per person per day. The mean daily flow rate was estimated using Equation (3) [11] as follows:

$$
Q=10^{-3} k q P_{d}+I+E
$$

where: $Q=$ design mean daily flow $\left(\mathrm{m}^{3} /\right.$ day), $k=$ wastewater return factor; $q=$ per capita water consumption (1/person/day), $P_{d}=$ design population; $I=$ infiltration of groundwater into a sewer line ( $\mathrm{m}^{3} /$ day), $E=$ industrial wastewater flow 
$\left(\mathrm{m}^{3} /\right.$ day $)$.

Wastewater return factor of 0.8 suggested for sewage project for the Government of Kenya [12] was used.

iv) Design Faecal coliform concentrations

Design faecal coliforms concentration of $5 \times 10^{7} \mathrm{FC}$ per $100 \mathrm{ml}$ in domestic wastewater [13] was used.

\subsection{Design Criteria and Analysis of the Waste Stabilization Ponds}

\section{a) Anaerobic Ponds}

The design and analysis of anaerobic ponds was based on permissible volumetric BOD loading and BOD removal [11] [14]. The volume of the anaerobic pond was determined using Equation (4) as follows:

$$
\lambda_{v}=\frac{L_{i} Q}{V_{a}}
$$

where: $\lambda_{v}$ volumetric organic loading rate $\left(\mathrm{g} / \mathrm{m}^{3} /\right.$ day); $L_{i}$ is the influent $\mathrm{BOD}$ $(\mathrm{mg} / \mathrm{l}) ; Q$ is the flow rate; and $V_{a}$ is the volume of the anaerobic pond.

The mean hydraulic retention time in the anaerobic was calculated using Equation (5) as follows:

$$
\theta_{a}=\frac{V_{a}}{Q}
$$

The effluent BOD in the anaerobic pond was determined as per Equation (6) [13] as applicable to Kenya.

$$
L_{e}=\frac{L_{i}}{1+K_{B O D} \theta_{a}}
$$

where: $\theta_{a}=$ hydraulic retention time in anaerobic pond (days); $L_{i}=$ influent BOD (mg/l); $L_{e}=$ effluent BOD into facultative pond $(\mathrm{mg} / \mathrm{l}) ; K_{B O D}=$ first order BOD removal constant rate $\left(\mathrm{d}^{-1}\right)$.

The first order BOD removal constant $\left(K_{B O D}\right)$ was determined as follows

$$
K_{B O D}=0.0207 T-0.202 \text { for } H R T>2 \text { days }
$$

where: $H R T=$ hydraulic retention time; $T=$ temperature $\left({ }^{\circ} \mathrm{C}\right)$

b) Facultative Ponds

Facultative ponds have been designed on the basis of permissible surface BOD loading [15] [16].

$$
\lambda_{s}=350[1.107-0.002 T]^{(T-25)}
$$

The hydraulic retention time in the facultative pond was computed using Equation (9) that takes full account of the impact of the evaporation rates that may be experienced in the housing estate especially in the hottest months of the year (May - October).

$$
\theta_{f}=\frac{2 A_{f} D}{\left[2 Q_{i}-0.001 A_{f} e\right]}
$$

The effluent BOD the facultative was calculated using Equation (10) [17] 


$$
L_{e}=\frac{L_{i}}{\left(1+k_{1} t\right)}
$$

where $k_{1}$ is a gross measure of bacterial activity described by an Arrhenius Equation (11) below:

$$
k_{1}=0.3 \theta^{(T-20)}
$$

The facultative pond was assumed to be lined with well compacted impermeable borrowed soils that will limit leakage of wastewater in the pond. Thus, effluent flow rate $\left(Q_{e}\right)$ was computed using Equation (12).

$$
Q_{e}=Q_{i}-0.001 A_{f} e
$$

\section{c) Maturation Ponds}

The design criteria for maturation ponds assumed a first order rate constant for bacterial die-off in the process. The formula used for coliform removal in a series of anaerobic, facultative and maturation ponds is as shown in Equation (13) [18]:

$$
\frac{N_{e}}{N_{i}}=\frac{1}{\left(1+K_{F C_{T}} \theta_{a}\right)\left(1+K_{F C_{T}} \theta_{f}\right)\left(1+K_{F C_{T}} \theta_{m 1}\right)\left(1+K_{F C_{T}} \theta_{m}\right)^{n}}
$$

where the faecal coliform die-off rate $\left(K_{F C_{T}}\right)$ is determined as per Equation (14)

$$
K_{F C_{T}}=2.6(\phi)^{T-20}
$$

The minimum hydraulic retention time in the first maturation pond was determined by using Equation (15) [19].

$$
\theta_{m 1}^{\min }=\frac{10 L_{i} H}{0.75 \lambda_{s f}}
$$

A minimum retention time of 3 days in maturation ponds that has been established to be adequate for East Africa was used [20]. The retention times and the number of subsequent maturation ponds was determined from Equation (16).

$$
\theta_{m}=\frac{\left[\frac{N_{i}}{N_{e}\left(1+K_{F C_{T}} \theta_{a}\right)\left(1+K_{F C_{T}} \theta_{f}\right)\left(1+K_{F C_{T}} \theta_{m}^{\min }\right)}\right]^{\frac{1}{n}}-1}{K_{F C_{T}}}
$$

The maturation pond area was calculated from Equation (17) as follows:

$$
A_{m}=\frac{2 Q_{i} \theta_{m}}{\left(2 D+0.001 e \theta_{m}\right)}
$$

d) Volumes of the Ponds

The volumes of the ponds were analyzed as follows [11] [21]:

$$
V=[(L W)+(L-2 s D)(W-2 s D)+4(L-s D)(W-s D)][D / 6]
$$

where: $V=$ pond volume $\left(\mathrm{m}^{3}\right) ; L=$ pond length at TWL $(\mathrm{m}) ; W=$ pond width at TWL $(\mathrm{m}) ; s=$ horizontal slope factor; $D=$ pond liquid depth $(\mathrm{m})$. 


\subsection{Design Criteria and Analysis of Constructed Wetlands}

The constructed wetlands analysed for wastewater treatment in Kaputiei housing estate were the vertical surface flow horizontal subsurface flow constructed wetland.

a) Vertical surface flow constructed wetlands

The design of the vertical surface flow constructed wetland was based on Equation (19) [22]:

$$
A_{1}=3.5 P E^{0.35}+0.6 P E
$$

The population equivalent was determined from Equation (20), as follows:

$$
\text { Population equivalent }(P E)=\frac{\text { daily BOD } \operatorname{load}(\mathrm{kg} / \text { day })}{0.06}
$$

b) Horizontal surface flow (HSSF) constructed wetlands

Equation (21) that has been widely used sizing HSSF constructed wetlands for domestic sewage treatment [23] was used as follows:

$$
A_{s}=\frac{Q\left(\ln C_{i}-\ln C_{e}\right)}{K_{T} d n}
$$

where $Q=$ average flow rate through the wetland $\left(\mathrm{m}^{3} /\right.$ day), $C_{e}=$ outlet effluent pollutant concentration $(\mathrm{mg} / \mathrm{l}), C_{i}=$ influent pollutant concentration $(\mathrm{mg} / \mathrm{l}) ; n=$ porosity (percent, expressed as decimal fraction), $d=$ depth of the wetland $(\mathrm{m})$, $K_{T}=$ Rate constant $\left(\right.$ day $\left.^{-1}\right)$

The effluent BOD from the constructed wetland was determined using Equation (22) as follows:

$$
\ln \left(\frac{C_{i}}{C_{e}}\right)=K_{T} t
$$

The rate constant,

$$
K_{T}=K_{R} \theta_{R}^{\left(T_{w}-T_{R}\right)}
$$

The values for the rate constant $K_{T}$ (rate constant, $K_{R}$; the temperature coefficient, $\theta$, and reference temperature, $T_{R}$ ) for both BOD and faecal coliforms were extracted from Table 1 as follows:

The hydraulic residence time (HRT) was calculated using Equation (24) as follows:

$$
t=\frac{n L W d}{Q}
$$

Table 1. Temperature coefficient for rate constants [23].

\begin{tabular}{ccc}
\hline Parameter & BOD $_{5}$ & Pathogen removal \\
\hline $\mathrm{T}_{\mathrm{R}}\left({ }^{\circ} \mathrm{C}\right)$ & 20 & 20 \\
$\mathrm{~K}_{\mathrm{R}}\left(\mathrm{day}^{-1}\right)$ & 1.104 & 2.6 \\
$\Theta$ & 1.06 & 1.19 \\
\hline
\end{tabular}


where: $n=$ effective porosity of media as a decimal; $L=$ length of bed (m); $W=$ width of bed (m); $d=$ average depth of liquid in bed $(\mathrm{m}) ; Q=$ average flow through the bed, $\mathrm{m}^{3} / \mathrm{d}$.

In analysing a suitable STS for the housing estate, alternative wastewater treatment systems were analysed in the following three scenarios:

Scenario 1: Re-sizing of the initial sewage treatment system;

Scenario 2: Optimization of the initial STS;

Scenario 3: Hybrid sewage treatment system.

\section{Results and Discussion}

\subsection{Design Flows (Q)}

The existing practices relate generated waste water to the per capita water consumption. The amount of wastewater generation is estimated as a factor of water consumption $(q)$ of 100 liters/capita/day. Wastewater return factor $(k)$ of 0.8 suggested [24] for sewage projects for the Government of Kenya was used in the design.

The domestic wastewater to be treated in Kaputiei Housing Estate was assumed to be conveyed through a PVC pipeline network and thus infiltration of groundwater into the sewer line was negligible. Thus, infiltration (I) and industrial wastewater flow (E) in Equation (3) were assumed to be zero. Therefore, the amount of generated sewage from the housing estate was estimated to be 1,753 $\mathrm{m}^{3} /$ day.

\subsection{Design BOD Concentration (Li)}

Kaputiei Housing Estate is a medium-size town. Thus, BOD contribution of 40 $\mathrm{g} /$ capita/day recommended for tropical countries was considered appropriate for estimation of the influent BOD [11]. Therefore, the design BOD concentration using Equation (2) was taken to be $400 \mathrm{mg} / \mathrm{l}$.

\subsection{Analysis of the Performance of the Initial STS}

The analysis of the initial STS was an attempt to comparatively calculate its capacity in handling the wastewater from the housing estate and associated limitations. The standard design models for the WSPs were used as a basis for the analysis as follows:

a) Anaerobic Pond

The analysis of the anaerobic pond was based on the design specifications that included: Water Depth $(D)=2.6 \mathrm{~m}$; Top Water Level: Length $(I)=60 \mathrm{~m}$; Width $(W)=37 \mathrm{~m}$; and $s=0.5$. The volume of the anaerobic pond $\left(V_{a}\right)$ computed using the Equation (5) [11] [21] was 5,450 $\mathrm{m}^{3}$ and the hydraulic retention time being 3 days which was more than minimum 1 day recommended for the design of anaerobic ponds [25].

The volumetric BOD loading in the anaerobic pond estimated using Equation (4) was $129 \mathrm{~g} / \mathrm{m}^{3} /$ day. The loading was considered to be within a permissible range of $100-400 \mathrm{~g} / \mathrm{m}^{3} /$ day that is recommended for designing anaerobic ponds 
in order to maintain anaerobic conditions and avoid release of odour [13].

With a BOD loading of $300 \mathrm{~g} / \mathrm{m}^{3} /$ day, the required volume of anaerobic pond was $2,337 \mathrm{~m}^{3}$. Therefore, the anaerobic pond was way above the expected capacity of $2,337 \mathrm{~m}^{3}$. Thus not making the most economic use of available land in the estate.

The effluent BOD from the above pond was simulated to $244 \mathrm{mg} / \mathrm{l}$ using a design temperature of $(\mathrm{T})$ of $20^{\circ} \mathrm{C}$ and first order BOD removal constant rate $\left(K_{B O D}\right)$ of 0.212 per day.

b) Facultative pond

The design specifications that form the basis for analyzing the facultative pond were: Water Depth $(\mathrm{D})=1.5 \mathrm{~m}$; Top Water Level: Length $(\mathrm{l})=148 \mathrm{~m}$; Width $(\mathrm{W})=42 \mathrm{~m}$. Thus, the Volume of the facultative pond was $9,111 \mathrm{~m}^{3}$ and surface area (Af) was $6,216 \mathrm{~m}^{2}$.

The permissible surface BOD loading as per Equation (5) [16] at design temperature of $20^{\circ} \mathrm{C}$ should be $253 \mathrm{~g} / \mathrm{m}^{3} /$ day. For this amount of BOD loading, the ideal surface area required was $16,906 \mathrm{~m}^{2}$. Therefore, the surface area of the facultative pond (i.e 6,216 $\mathrm{m}^{2}$ ) was below the anticipated size by $10,690 \mathrm{~m}^{2}$.

For this surface area and considering net evaporation rate in Kaputiei Housing Estate of $12 \mathrm{~mm} /$ day, retention time in the facultative pond $\left(\theta_{f}\right)$ was determined to be 5 days. Therefore, the effluent BOD $\left(L_{e}\right)$ calculated using Equation (10) was $97.7 \mathrm{mg} / \mathrm{l}$ and the flow rate of the partially treated being $678 \mathrm{~m}^{3} /$ day.

\section{c) Maturation Pond}

Design specifications of the maturation pond were: Water Depth $(D)=1.1 \mathrm{~m}$; Top Water Level: Length $(l)=148 \mathrm{~m}$; Width $(\mathrm{W})=42 \mathrm{~m}$; and Influent flow rate $(Q i)=1,474 \mathrm{~m}^{3} /$ day.

Based on Equation (5), the volume of maturation pond $\left(V_{m}\right)$ was $6,723 \mathrm{~m}^{3}$ and Surface area $\left(A_{m}\right)$ of $6,216 \mathrm{~m}^{2}$.

The hydraulic retention time in the maturation pond determined by Equation (17) was 4 days which was above the minimum 3 days that has been established to be adequate for maturation ponds in East Africa [20]. This meant that there would be minimal rates of hydraulic short-circuiting and algal washout in the pond [18]. The rate of faecal coliform removal in a series of anaerobic, facultative and maturation ponds determined by applying Equation (8) [18] was 35,600 FC per $100 \mathrm{ml}$. This was way above 1,000 FC per $100 \mathrm{ml}$ that are recommended by WHO if the treated wastewater was to be used for unrestricted crop irrigation. From the maturation pond, the effluent BOD was determined to be $44 \mathrm{mg} / \mathrm{l}$ which was also way above the recommended $25 \mathrm{mg} / \mathrm{l}$ for discharge into the water bodies. The analysis showed that the initial STS was not going to be sufficient for the treatment of the domestic wastewater to acceptable effluent discharge standards.

\subsection{Analysis and Selection of Suitable STS}

A suitable biological sewage treatment, based on the design input parameters, would be selected on account of BOD reduction and faecal coliform removal as 
critical parameters.

Scenario 1: Re-sizing of the Initial STS

In this scenario, the actual sizes of the waste stabilization ponds required in order to achieve acceptable wastewater treatment discharge standards are common traditional designs of anaerobic, facultative and maturation ponds.

a) Anaerobic Pond

The design of the actual size of anaerobic pond was based on permissible volumetric BOD loading $\left(\lambda_{v}\right)$ of $300 \mathrm{~g} / \mathrm{m}^{3} /$ day usually below the upper limit of $400 \mathrm{~g} / \mathrm{m}^{3} /$ day recommended to avoid risks of odour production [15]. Thus, it was suitable in determining the actual size of the anaerobic pond.

The volume of the anaerobic pond determined using Equation (7) was 2,337 $\mathrm{m}^{3}$. By assuming a design depth of $2.5 \mathrm{~m}$, the surface area of the anaerobic pond was $935 \mathrm{~m}^{2}$. The hydraulic retention time in the anaerobic pond using Equation (6) was 3 days which was above the minimum design value of 1 day recommended for the design of anaerobic ponds [25]. The BOD removal in the anaerobic pond determined using Equation (6) was $314 \mathrm{mg} / \mathrm{l}$.

b) Facultative Pond

The design of facultative pond was based on permissible surface BOD loading $\left(\lambda_{S}\right)$, Equation (8). By using a design temperature of $20^{\circ} \mathrm{C}$, the $\lambda_{S}$ is as $253 \mathrm{~g} / \mathrm{m}^{3} /$ day. With this BOD loading, the surface area determined using Equation (7) was $21,757 \mathrm{~m}^{2}$.

The hydraulic retention time in the facultative pond computed using Equation (9) and a design depth of $1.5 \mathrm{~m}$ was 3 days which was above the acceptable minimum value of 4 days that is usually adopted for design temperatures that are above $20^{\circ} \mathrm{C}$. Therefore suitable in minimizing hydraulic short-circuiting and preventing algal washout.

\section{c) Maturation ponds}

The hydraulic retention time in the maturation pond as per Equation (15) was found to be 2.4 days which is less than the recommended minimum of 3 [18]. Therefore, $\theta_{m 1}$ of 3 days was used in the design. Thus, the area of the first maturation pond being $4,397 \mathrm{~m}^{2}$ and the effluent BOD being $23.7 \mathrm{mg} / \mathrm{l}$. Thus, the effluent flow from the first maturation pond would be $1,463 \mathrm{~m}^{3} / \mathrm{day}$ ).

The influent faecal coliforms $\left(N_{i}\right)$ of $5 \times 10^{7} \mathrm{FC}$ per $100 \mathrm{ml}$ [13] and effluent faecal $\left(N_{e}\right)$ of 1,000 FC per $100 \mathrm{ml}$ that are recommended by WHO are used in Equation (18) to determine the hydraulic retention time in subsequent maturation ponds. By allocating random values to $\mathrm{n}$ and solving for the hydraulic retention time, the following outputs resulted:

For:

- Combination 1: $n=1, \theta_{m}=9$ days

- Combination 2: $n=2, \theta_{m}=1.5$ days

- Combination 3: $n=3, \theta_{m}=0.7$ days

From the above combinations, using two maturation ponds was considered to provide the recommended minimum time hydraulic retention time of 3 days. The area of $M_{2}$ was determined to be $4,397 \mathrm{~m}^{2}$ (same as for $M_{1}$ ). Therefore, ef- 
fluent BOD was $12.5 \mathrm{mg} / \mathrm{l}$ and effluent flow from maturation pond $M_{2}$ would be $1,425 \mathrm{~m}^{3} /$ day.

Scenario 1 which presents the actual sizes of anaerobic, facultative and maturation required to treat domestic wastewater in the housing estate would give satisfactory treatment performance both in terms of BOD and faecal coliform reductions as summarized in Table 2 above. However, the only limiting factor is the size of land required which is above the currently available land. Thus, the analysis proceeded to scenario 2 .

Scenario 2: Optimization of the initial STS

In this scenario, the anaerobic pond of the initial STS was considered to remain as a constant and the facultative and maturation ponds portioned into two ponds in order to obtain optimal wastewater treatment:

\section{Anaerobic ponds}

The design specifications and the projected wastewater treatment performances of the initial anaerobic pond will be maintained in the optimized design as follows:

- Water Depth $(\mathrm{D})=2.6 \mathrm{~m}$

- Influent flow rate $=1753 \mathrm{~m}^{3} /$ day

- Hydraulic retention time $=3$ days

- Effluent BOD = $244 \mathrm{mg} / \mathrm{l}$

Facultative ponds $F_{1}$ and $F_{2}$

The initial facultative pond was split into two equal ponds $F_{1}$ and $F_{2}$ with the following design specifications.

Water Depth $(\mathrm{D})=1.5 \mathrm{~m}$

Top Water Level: Length (l) $=72 \mathrm{~m}$; Width $(\mathrm{W})=42 \mathrm{~m}$

From the above design specifications, the volume and the surface area of each facultative pond as per Equation (5) will be $4,409 \mathrm{~m}^{3}$, Surface area $\left(A_{f}\right)$ being $3,024 \mathrm{~m}^{2}$ and the hydraulic retention time in the facultative pond $F_{1}$ computed using Equation (9) being 3 days. With this retention time and an influent BOD of $244 \mathrm{mg} / \mathrm{l}$, the anticipated BOD concentration in the effluent will be $128 \mathrm{mg} / \mathrm{l}$ and the Effluent from rate from $F_{1}$ being $1,717 \mathrm{~m}^{3} /$ day.

The hydraulic retention time in $F_{2}$ was analyzed to be 2.7 days and an Effluent of $71 \mathrm{mg} / \mathrm{l}$. In this scenario, the effluent from the facultative pond $F_{2}$ was less than the $97.6 \mathrm{mg} / \mathrm{l}$ in the initial STS. This meant that better treatment was

Table 2. Analysis of well sized WSPs (Scenario 1).

\begin{tabular}{|c|c|c|c|c|c|}
\hline WSP & Pond & $\begin{array}{l}\text { Surface area } \\
\left(\mathrm{m}^{2}\right)\end{array}$ & $\begin{array}{l}\text { Hydraulic retention } \\
\text { time (days) }\end{array}$ & $\begin{array}{l}\text { Effluent BOD } \\
\qquad(\mathrm{mg} / \mathrm{l})\end{array}$ & $\begin{array}{l}\text { Effluent faecal coliforms } \\
\text { (FC per } 100 \mathrm{ml})\end{array}$ \\
\hline Anaerobic & A & 935 & 1.3 & 314 & $11,415,525$ \\
\hline Facultative & $\mathrm{F}$ & 21757 & 20 & 45 & 215,387 \\
\hline \multirow{2}{*}{ Maturation } & $\mathrm{M}_{1}$ & 4397 & 3 & 23.7 & 24,476 \\
\hline & $\mathrm{M}_{2}$ & 4397 & 3 & 12.5 & 1,000 \\
\hline \multicolumn{2}{|c|}{ TOTAL } & 31,486 & 27.3 & & \\
\hline
\end{tabular}


achieved when the facultative pond was partitioned. The combined BOD removal in the anaerobic pond and facultative ponds in this scenario was $82.2 \%$ and was greater than $80 \%$ for temperatures above $20^{\circ} \mathrm{C}$ [13]. Thus, the partitioning was considered adequate.

Maturation Ponds $M_{1}$ and $M_{2}$

The analysis considered partitioning of the initial maturation pond into two equal ponds with a water depth (D) of $1.1 \mathrm{~m}$ and equal volumes $(\mathrm{Vm})$ of 3,258 $\mathrm{m}^{3}$ and the surface area $(\mathrm{Am})$ of $3,024 \mathrm{~m}^{2}$. With this, the effluent BOD was anticipated at $44.4 \mathrm{mg} / \mathrm{l}$ and the effluent flow rate being $1,645 \mathrm{~m}^{3} /$ day. The hydraulic retention time $\theta_{m 2}$ obtained was 2 days BOD in the effluent of $27.8 \mathrm{mg} / \mathrm{l}$. Through partitioning of the initial maturation pond, a BOD of $27.8 \mathrm{mg} / \mathrm{l}$ was achieved. This was lower than the $44.4 \mathrm{mg} / \mathrm{l}$ in the initial STS. With faecal coliform die-off rate $\left(K_{F C_{T}}\right)$ determined previously as 2.6 and a design influent faecal coliform concentration of $5 \times 10^{7} \mathrm{FC}$ per $100 \mathrm{ml}$, the effluent FC $\left(N_{e}\right)$ gave $2,094 \mathrm{FC}$ per $100 \mathrm{ml}$ and this was way below the $35,600 \mathrm{FC}$ per $100 \mathrm{ml}$ in the initial STS.

\section{Analysis of scenario 2 for the initial and future populations}

In the design of an STS for the initial and future populations, there was need to analyze Scenario 2 for the treatment of the wastewater. The design assumption was population of 10,000 with waste water generation of $800 \mathrm{~m}^{3} /$ day and Volumetric BOD being $58 \mathrm{~g} / \mathrm{m}^{3} /$ day. The future population (i.e. 10 years after implementation of the STS) was projected to be 14,802 people with an estimated wastewater production of $1184 \mathrm{~m}^{3} /$ day and Volumetric BOD of $87 \mathrm{~g} / \mathrm{m}^{3} /$ day.

Thus, the use of the initial anaerobic pond would contribute to volumetric BOD loading that was way below $300 \mathrm{~g} / \mathrm{m}^{3} /$ day suitable at a design temperature of $20^{\circ} \mathrm{C}$ and the minimum $100 \mathrm{~g} / \mathrm{m}^{3} /$ day in order to prevent anoxic reactions in anaerobic ponds [13]. The initial anaerobic pond was not therefore suitable for use in the two cases.

In order to ensure proper utilization of available land, there was need to design an anaerobic pond which can satisfactorily handle wastewater for the two cases.

The required volume of the anaerobic pond for the future population determined from Equation (7) was $1,579 \mathrm{~m}^{3}$. With an initial flow rate of $800 \mathrm{~m}^{3} /$ day, the volumetric BOD loading was $203 \mathrm{~g} / \mathrm{m}^{3} /$ day. The above BOD loading was within the permissible range of $300 \mathrm{~g} / \mathrm{m}^{3} /$ day. Thus, with a retention time determined as 1.3 days and effluent BOD of $314 \mathrm{mg} / \mathrm{l}$, the pond was considered appropriate in handling wastewater for the initial and future population.

The facultative and the maturation ponds in scenario 2 will be utilized in the estate for the present and future populations. Thus, $F_{1}$ and $F_{2}$ will have a design surface area of 3,024 $\mathrm{m}^{2}$. Thus, the hydraulic retention time in facultative pond $F_{1}$ will be 4 days and the anticipated BOD concentration in the effluent of 143 $\mathrm{mg} / \mathrm{l}$ and flow of $1,148 \mathrm{~m}^{3} /$ day.

As for $F_{2}$, the hydraulic retention time was determined to be 4 days, effluent BOD concentration $\left(L_{e}\right)$ of $65 \mathrm{mg} / \mathrm{l}$ and flow rate of $1,112 \mathrm{~m}^{3} /$ day. The hydraulic 
retention time in $M_{1}$ will be 3 days, effluent BoD of $34.2 \mathrm{mg} / \mathrm{l}$ and effluent flow rate from $M_{1}$ will be $1,076 \mathrm{~m}^{3} /$ day.

With the above flow rate, the hydraulic retention time in Maturation Pond 2 was determined to be 3.1 days and Effluent BOD of $21 \mathrm{mg} / \mathrm{l}$. With a design influent faecal coliform concentration of $5 \times 10^{7} \mathrm{FC}$ per $100 \mathrm{ml}$, the effluent FC from $M_{2}$ will be $1,101 \mathrm{FC}$ per $100 \mathrm{ml}$.

From the above design, the faecal coliforms in the effluent were not be satisfactory, thus, the need to re-design $M_{2}$ to have a HRT of 3.5 days and surface areas of 3,360 in order to get an effluent BOD of $16.7 \mathrm{mg} / \mathrm{l}$ and with at most 1,000 FC per $100 \mathrm{ml}$.

For the initial and future population, the above STS will provide satisfactory treatment. Thus, with $M_{2}$ of $3360 \mathrm{~m}^{2}$ and a flow rate of $1,645 \mathrm{~m}^{3} /$ day for the ultimate population, HRT $\left(\theta_{m 2}\right)$ will be 2.2 days and the BOD in the effluent of $26.7 \mathrm{mg} / \mathrm{l}$. The effluent flow rate from $M_{2}$ will be $1,605 \mathrm{~m}^{3} /$ day and the faecal coliforms removal will be $1,932 \mathrm{FC}$ per $100 \mathrm{ml}$.

The anticipated effluent faecal coliforms in this scenario are way below the $35,600 \mathrm{FC}$ per $100 \mathrm{ml}$ in the initial STS.

In summary, scenario 2 which involved partitioning of the initial facultative pond and the maturation pond gave better treatment performance when compared to the initial STS in terms of both BOD and faecal coliforms removal. However, for the initial and the future populations, the use of the initial anaerobic pond which is appropriate for the ultimate population was considered not appropriate since the volumetric BOD loading would be too low. Thus, an additional treatment system selected for the ultimate population was a constructed wetland. A hybrid system that incorporates both the STS of WSPs in scenario 2 and a constructed wetland analysed under scenario 3.

\section{Scenario 3: Hybrid wastewater treatment system}

The hybrid STS consisted of the optimized initial STS and a constructed wetland (CW). In order to achieve better treatment performance, the CW adopted for the purification pond was that of German Pure Reedbed Technology which incorporates both the vertical flow and the horizontal subsurface flow in the Gravel Bed Hydroponics (Figure 1).

i) Design of the vertical surface flow (VSF) GBH

The design of the vertical surface flow constructed wetland based on Equation

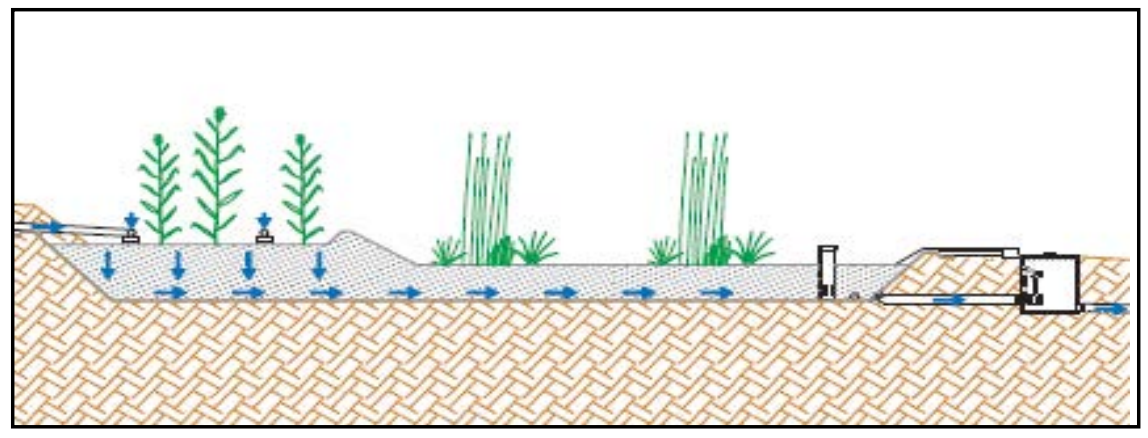

Figure 1. Cross-Section of the purification Bed of a Pure Reedbed STS [26]. 
(21) and (19) was $465 \mathrm{~m}^{2}$ and the hydraulic retention time $(t)$ in the VSF being 0.1 days. By assuming a rate constant $K_{T}$ for BOD removal as 09.3 in Equation (22), the effluent BOD as per Equation (22) was $24.3 \mathrm{mg} / \mathrm{l}$. Thus, the rate constant $\left(K_{T}\right)$ for faecal coliform removal determined as per Equation (22) was 1.54.

Therefore, one cell of the vertical flow bed was considered adequate in providing effluent faecal coliforms amounting to 1,674 FC per $100 \mathrm{ml}$.

ii) Design of the horizontal subsurface flow (HSSF) $G B H$

The design input parameters for sizing and evaluating the performance of the HSSF GBH were:

1) Influent $\operatorname{BOD}\left(C_{i}\right)=24.3 \mathrm{mg} / \mathrm{l}$

2) Influent $\mathrm{FC}=1674 \mathrm{FC}$ per $100 \mathrm{ml}$

3) Effluent BOD $\left(C_{e}\right)=20 \mathrm{mg} / \mathrm{l}$

4) Depth of the GBH $(d)=0.6 \mathrm{~m}$

5) Media $=$ Gravel of diameter $32 \mathrm{~mm}$ and porosity ( $n$ ) of 0.4

The surface area of the HSSF $\left(A_{h}\right)$ determined using Equation (21) [23] was $1,396 \mathrm{~m}^{2}$

With the above surface area, the hydraulic residence time $(t)$ was 0.2 days and the effluent flow $\left(Q_{e}\right)$ rate of $1,587 \mathrm{~m}^{3} /$ day and $195 \mathrm{FC}$ per $100 \mathrm{ml}$.

For scenario 3, a summary of the analysis based on the ultimate population is as shown in Table 3:

A summary of the analysis of alternative STSs for Kaputiei Housing Estate based on the ultimate population in terms of land area required and the anticipated treatment performances is as shown in Table 4:

Table 3. Analysis of the hybrid STS (scenario 3).

\begin{tabular}{cccccc}
\hline STS & Pond & $\begin{array}{c}\text { Surface area } \\
\left(\mathrm{m}^{2}\right)\end{array}$ & $\begin{array}{c}\text { Hydraulic retention time } \\
(\text { Days })\end{array}$ & $\begin{array}{c}\text { Effluent BOD } \\
(\mathrm{mg} / \mathrm{l})\end{array}$ & $\begin{array}{c}\text { Effluent faecal coliforms } \\
(\mathrm{FC} \text { per 100 ml) }\end{array}$ \\
\hline Anaerobic pond & $\mathrm{A}$ & 2220 & 3 & 244 & $5,681,818$ \\
Facultative ponds & $\mathrm{F}_{1}$ & 3024 & 3 & 128 & 645,661 \\
& $\mathrm{~F}_{2}$ & 3024 & 2.7 & 71 & 80,506 \\
Maturation ponds & $\mathrm{M}_{1}$ & 3024 & 2 & 26.4 & 12,985 \\
& $\mathrm{M}_{2}$ & 3360 & 2.2 & 24.3 & 1,932 \\
Constructed Wetland & $\mathrm{VSF}$ & 465 & 0.1 & 20 & 1674 \\
TOTAL & $\mathrm{HSSF}$ & 1396 & 0.2 & & 195 \\
\hline
\end{tabular}

Table 4. Comparison of the alternative STSs analyzed.

\begin{tabular}{cccc}
\hline STS & Surface area required $\left(\mathrm{m}^{2}\right)$ & Effluent BOD (mg/l) & Effluent faecal coliforms (FC per 100 ml) \\
\hline Initial STS & 14,652 & 44.4 & 35,600 \\
Well sized WSPs (Scenario 1) & 31,486 & 12.5 & 1,000 \\
Optimized initial STS (Scenario 2) & 14,316 & 26.7 & 1,932 \\
Hybrid STS (Scenario 3) & 16,513 & 20 & 195 \\
\hline
\end{tabular}


From the summarised results in Table 4, the Hybrid STS analysed in scenario 3 provided best effluent performances that meets acceptable discharge limits to the environment.

Figure 2 shows the output of the analysis that compared the initial STS and the alternative scenarios both in terms of surface areas and the anticipated treatment performances in BOD and faecal coliforms in the effluent.

As shown in Figure 3 and Figure 4, the two alternatives that can provide

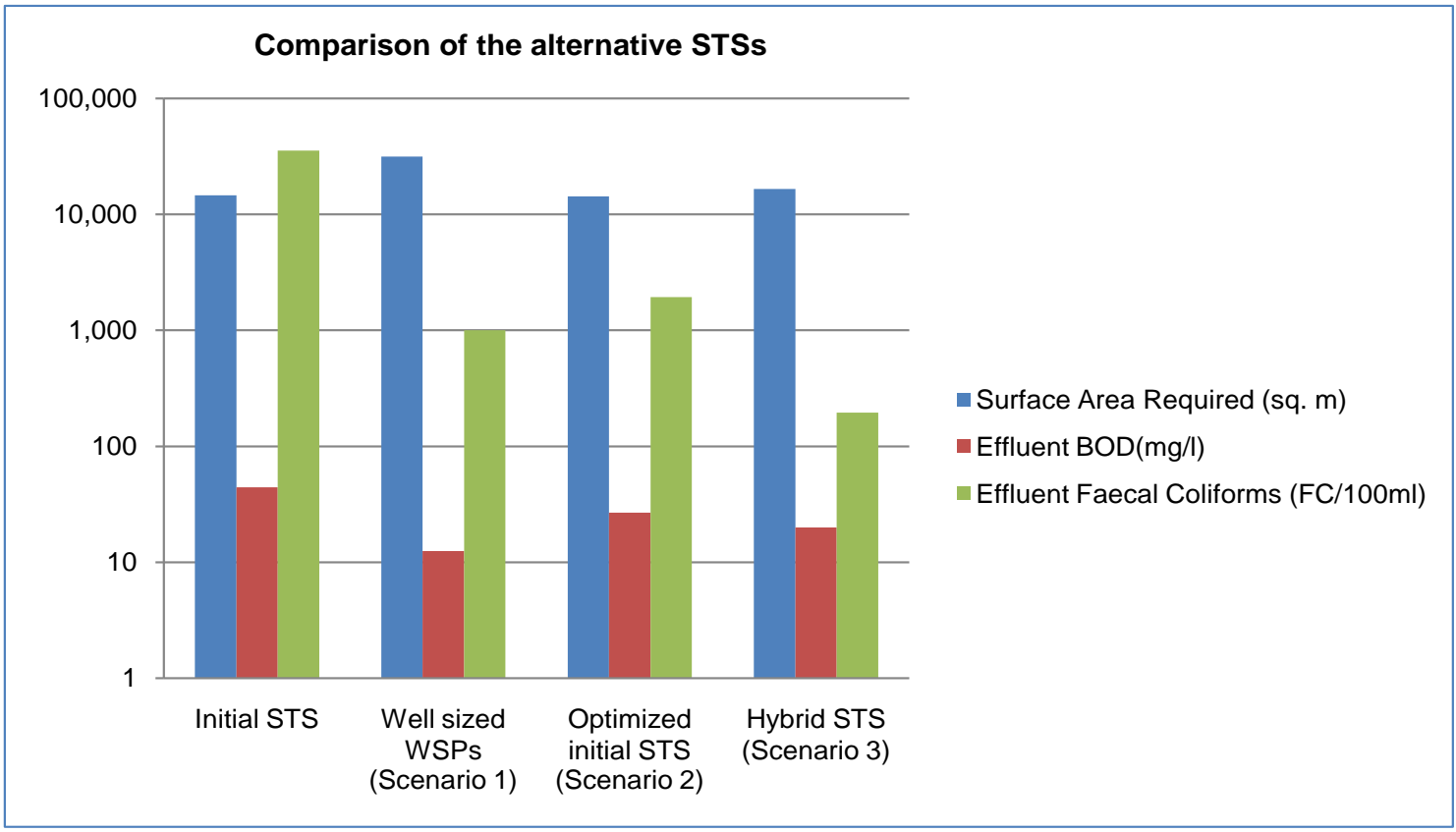

Figure 2. Comparison of alternative STSs in terms of surface area and treatment performances.

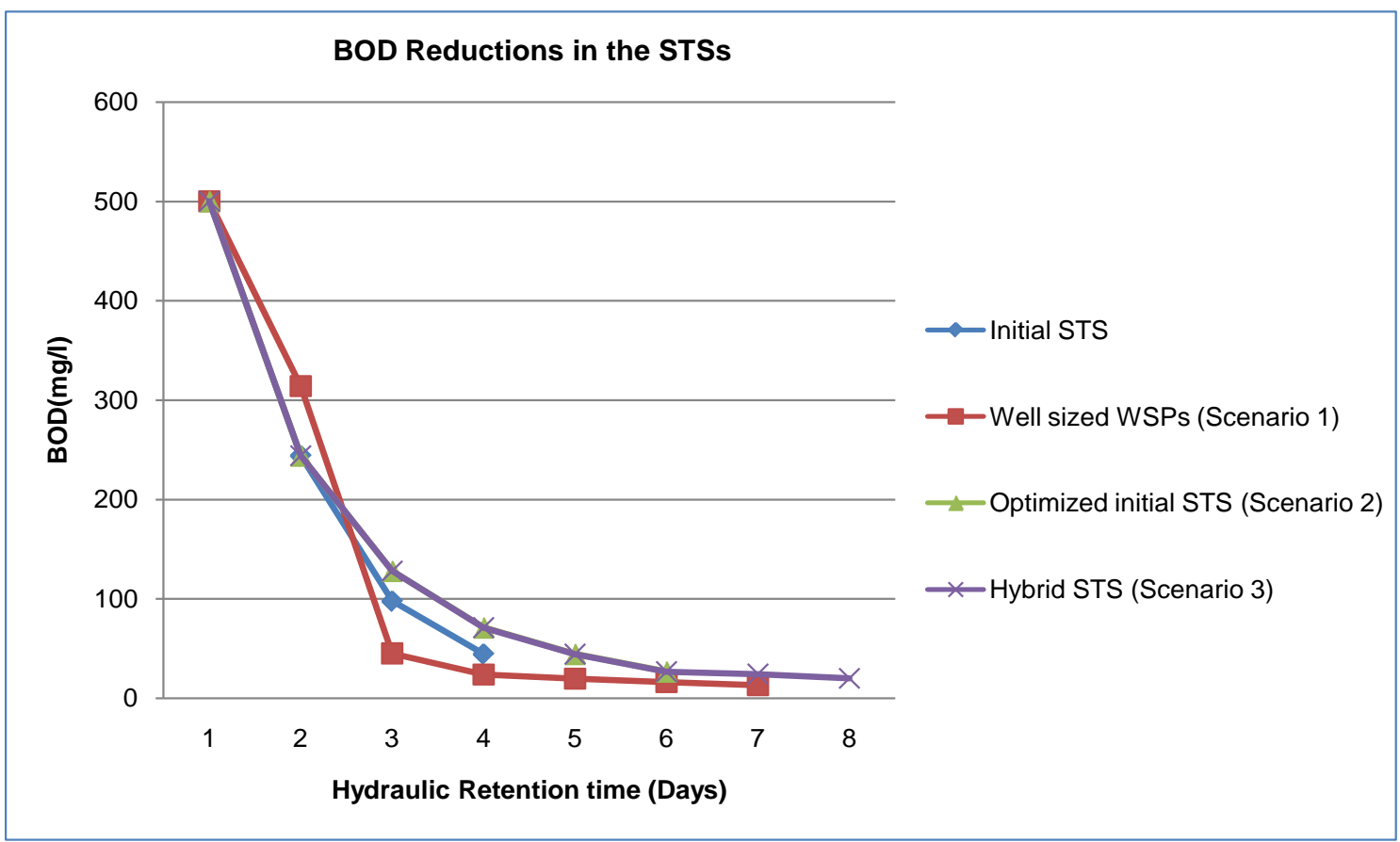

Figure 3. Comparison of BOD reduction in the alternative STSs. 


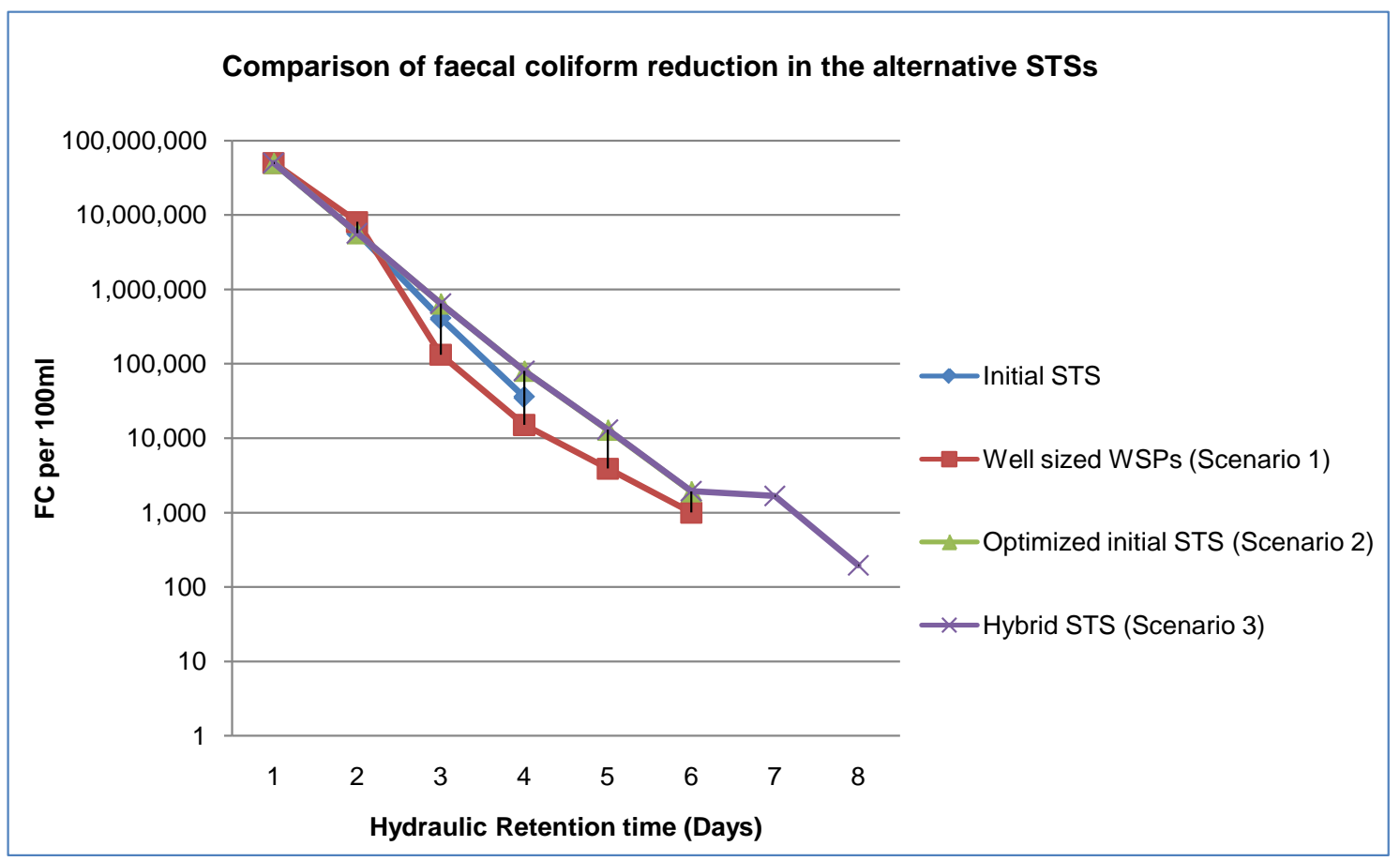

Figure 4. Comparison of faecal coliform reduction in the alternative STSs.

satisfactory treatment performances include well sized WSPs (Scenario 1) and the hybrid STS (Scenario 3). The only limitation with scenario 1 was the large amount of land required. Thus, the hybrid STS was considered appropriate for wastewater treatment in the estate both in terms of land area required and projected treatment performance.

\section{Conclusion}

Based on this study, the objective of selecting a hybrid sewage treatment system for wastewater treatment in the housing estate demonstrated excellent wastewater purification performance in both BOD reduction and faecal coliform removal within the available land area in the housing estate. The incorporation of a constructed wetland in the hybrid system reduced the overall land area required for treatment by approximately half that was required for well sized WSPs. The treated effluent discharge from the hybrid STS with a BOD of $20 \mathrm{mg} / \mathrm{l}$ and $195 \mathrm{FC}$ per $100 \mathrm{ml}$ was acceptable for unrestricted crop irrigation and thus would be reused in the housing estate for kitchen gardening and agroforestry.

\section{References}

[1] WHO (2004) Development Goals: Sanitation Target Out of Reach for Many Countries. Bulletin of the World Health Organization, World Health Organization, Geneva.

[2] Viessman, W. and Hammer, M.J. (1993) Water Supply and Pollution Control. 5th Edition, Harper Collins College Publishers, New York.

[3] Chara, J., Pedraze, G. and Conde, N. (1999) The Productive Decontamination System: A Tool for Protecting Water Resources in the Tropics. Livestock Research and Rural Development, 11, 25-35. 
[4] Eckenfelder Jr., W.W. (1989) Industrial Wastewater Pollution Control. McGrawHill, New York.

[5] United Nations Environment Program (UNEP) (1999) UNEP/Global Program of Action Strategic Action Plan to Address Sewage as a Major Land-Based Pollutant. UNEP Second Global Meeting of Regional Seas Conventions and Action Plans, Hague.

[6] Wright, A. (1999) Toward a Strategic Sanitation Approach: Improving Sustainability in Developing Countries.

[7] Lier, J.B. and Lettinga, G. (1999) Appropriate Technologies for Effective Management of Industrial and Domestic Wastewaters: The Decentralized Approach. Water Science and Technology, 40, 171-184.

[8] British Broadcasting Corporation (BBC) (2004) Sanitation in Developing Countries.

[9] Barongo and Mathu (2002) Ground Water Survey Report for Kaputuei, Kajiado-Kenya.

[10] Mara, D.D. and Pearson, H.W. (1986) Artificial Freshwater Environments: Waste Stabilization Ponds. In: Schoenborn, W., Ed., Biotechnology, Vol. 8, 177-206.

[11] Mara, D.D. and Pearson, H.W. (1998) Waste Stabilization Ponds: Design Manual for Mediterranean Europe. Lagoon Technology International Ltd., Leeds.

[12] WHO (1993) Guidelines for Drinking-Water Quality. 2 Edition, World Health Organization, Geneva and HMSO, London.

[13] Mara, D.D., Pearson, H.W., Alabaster, G.P. and Mills, S.W. (1997) An Evaluation of Waste Stabilization Ponds in Kenya. The Research Monograph No. 11, University of Leeds, Department of Civil Engineering, Leeds.

[14] Mara, D.D., Pearson, H.W., Oragui, J.I., Arridge, H. and Silva, S.A. (1997) Development of a New Approach to Waste Stabilization Pond Design. The Research Monograph No. 5, University of Leeds, Department of Civil Engineering, Leeds.

[15] Mara, D.D. (1986) Sewage Treatment in Hot Climates. John Wiley \& Sons Ltd., Chichester, West Sussex, UK.

[16] Von Sperling, M. (1999) Performance Evaluation and Mathematical Modelling of Coliform Die-Off in Tropical and Subtropical Waste Stabilization Ponds. Water Science and Technology, 33, 1435-1448.

[17] Marais, G.V.R and Shaw, V.A. (1961) A Rational Theory for the Design of Sewage Stabilization Ponds in Central and South Africa. Transactions of the South African Institute of Civil Engineers, 3, 205-227.

[18] Marais, G.V.R. (1974) Faecal Bacteria Kinetics in Waste Stabilization Ponds. Journal of the Environmental Engineering Division, 100, 119-139.

[19] Mara, D.D. (1997) Design Manual for Waste Stabilization Ponds in India. Lagoon Technology International Ltd., Leeds, England.

[20] Mara, D.D. (1998) Proposed Design for Oxidation Ponds in Hot Climates. Journal ASCE-EE, 101, 296-300.

[21] EPA (1983) Design Manual: Municipal Wastewater Stabilization Ponds. Report No. EPA-25/1-83-015, Environmental Protection Agency, Municipal Environmental Research Information, Cincinnati, $\mathrm{OH}, 122$.

[22] O’Hagan, S. (2003) The Design, Operation and Performance of a Municipal Hybrid Reed Bed Treatment. Water Science \& Technology, 48, 119-126.

[23] Reed, S.C., Crites, R.W. and Middlebrooks, E.J. (1995) Natural Systems for Waste Management and Treatment. 2nd Edition, McGraw Hill, New York.

[24] World Bank Water and Sanitation Program, Washington DC.

[25] Meiring, P.G., Drews, R.J., van Eck, H. and Stander, G.J. (1998) A Guide to the Use of Pond Systems in South Africa for the Purification of Raw and Partially Treated Sewage.

[26] Rausch, W.D. (2008) Design of a Pure Reedbed Sewage Treatment Plant (PURERSTS), the German Design of a Wastewater Management System. 
Submit or recommend next manuscript to SCIRP and we will provide best service for you:

Accepting pre-submission inquiries through Email, Facebook, LinkedIn, Twitter, etc. A wide selection of journals (inclusive of 9 subjects, more than 200 journals)

Providing 24-hour high-quality service

User-friendly online submission system

Fair and swift peer-review system

Efficient typesetting and proofreading procedure

Display of the result of downloads and visits, as well as the number of cited articles Maximum dissemination of your research work

Submit your manuscript at: http://papersubmission.scirp.org/

Or contact gep@scirp.org 